\title{
PHYTOPLANKTON COMMUNITY OF RIVER MINHO (INTERNATIONAL SECTION)
}

\author{
Vitor Vasconcelos ${ }^{1,2}$ and Manuela Cerqueira ${ }^{1}$ \\ ${ }^{1}$ Departamento de Zoologia e Antropologia. Faculdade de Ciências da Universidade do Porto. Praça \\ GomesTeixeira - 4050 Porto. ${ }^{2}$ CIMAR - Interdisciplinary Center of Marine and Environmental Research - R. \\ Campo Alegre -4000 Porto
}

\begin{abstract}
The phytoplankton community of the international section of river Minho was studied during the spring-summer periods 1989 and 1999. Samples were collected not on a regular basis from S. Gregório (mostly in the upstream international section) to Caminha, at the Minho estuary. According to our results, eutrophication seems to decrease from upstream to downstream sites. The occurrence of cyanobacteria blooms, especially of Microcystis aeruginosa, in the Minho River mainly in August suggests that they may be formed in Spanish reservoirs and then float downstream into the studied section. These data clearly show that the monitoring of cyanobacteria in Minho River is important. Data can he used to prevent human health risks, as this water is used for drinking, recreation and shellfish harvest.
\end{abstract}

Keywords: phytoplankton, Minho River, Cyanobacteria. eutrophication

RESUMEN

Durante los periodos de primavera-verano de 1989 y 1999 se ha estudiado la comunidad fitoplanctónica del tramo internacional del rio Miiio. La muestras se tomaron de forma irregular desde Santa Gregória (la localidad más alejada del tramo internacional) hasta Caminha, ya en el estuario del Miño. De acuerdo con nuestro resultados la eutrofización parece decrecer aguas abajo. La presencia de floraciones de cianobacterias, especialmente de Microcystis aeruginosa, en el río Miño, pi-incipalmente en Agosto, indica que pueden haberse formado en los embalses españoles y que después flotan aguas ahajo. Este dato muestra claramente que el seguimiento de las cianobacterias en el río Miiio es importante para prevenir riesgos para la salud humana ya que el agua es usada para beber, uctividades recreativas v el cultivo de marisco.

Palabras clave: fitopláncton, nio Miiio, cianobacterias, eutrofización.

\section{INTRODUCTION}

The phytoplankton communities of slow-flowing rivers are influenced by the development of communities in upstream reservoirs with species typical from sites with higher retention time.

Minho River has a total length of $350 \mathrm{~km}$ and a drainage area of $14,000 \mathrm{~km}^{2}$, half of it in Galicia (North-West Spain). The river is dammed at several points in Spain. In the international section of this river there are no dams, although one is being projected for the Melgaço area. As a whole, the lithology of the drainage area is dominated by hard materials of low solubility (MartÍnez-Ansemil \& Membiela, 1992).

Not much data are available concerning the phytoplankton of this river. Cerqueira (1991) analysed samples of the phytoplankton community of Minho river, one in autumn 1989 and another in Spring 1990. Vasconcelos (1995a) collected blooms of the cyanobacteria Microcystis aeruginosa at the estuary of Minho river in August 1990 and 1991. At this time M. aeruginosa composed more than $94 \%$ of the total phytoplankton density. Nevertheless, at these times the blooms showed no toxicity by the mouse bioassay.

Limnological studies in Minho River are very scarce, which is also true of other NW Iberian rivers, so it is important to contribute to the knowledge of the limnological biodiversity of this area of the Iberian Peninsula.

The objective of the present paper is to contribute to the analysis of the phytoplankton com- 
munity of the international section of Minho river with a special emphasis on cyanobacteria.

\section{MATERIAL AND METHODS}

Samples analysed in this work were collected, from 1989 to 1999 , in different sites in the international section of River Minho (Fig. 1). As these results combine data from several different projects there is no even periodicity nor all the sites were sampled always at the same time. In all the dates, samples were collected with a Ruttner bottle at the surface of the river. In the sites closer to the mouth of the river (Valenga to Tamuge), samples were collected during low tide so as to prevent any contamination with marine phytoplankton species.

Samples for phytoplankton analysis were immediately preserved in Lugol solution. Phytoplankton quantification of preserved samples was done using 5 and $25 \mathrm{ml}$ Utermohl sedimentation chambers. Preserved samples were allowed to sediment during a period of 12 to 18 hours. The counting was done with an inverted microscope at a 400x magnification. Several transects were counted, according to the method described in Lund et al. (1958). Results are presented as average number of cells per millilitre.

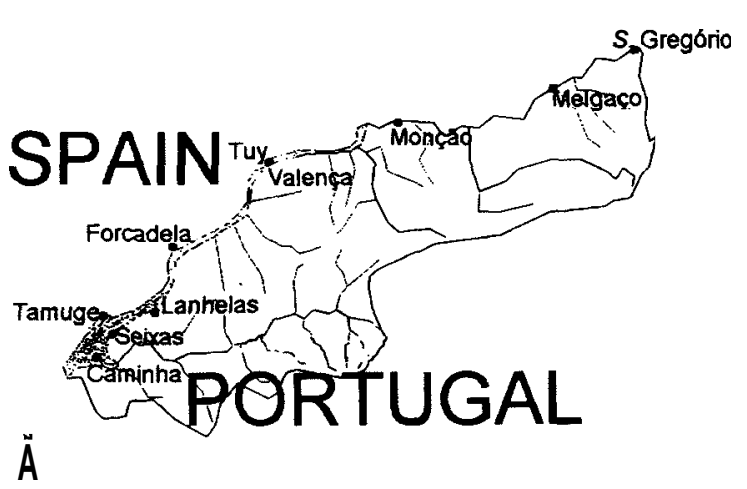

Figure 1. Location of the sampling sites in the international section of Minho river (1989-1999) (viewed from the Portuguese drainage area). Situación de las estaciones de muestreo en el tramo interna cional del río Miño (1989-1999) (vista desde la cuenca Portuguesa).
Cyanobacteria, namely Microcystis cells, were counted according to Chorus \& Bartram (1999). Whenever colonies were found and when cells were very dense in the colony, the average biovolume of at least 20 colonies and of 20 unicells were calculated. The average cell number was obtained by dividing the average colony volume by the average cell volume.

\section{RESULTS AND DISCUSSION}

A total of 79 phytoplankton species were recorded in the international section of River Minho (Table 1), without taking into account other phytoplankton organisms which could not be identified to species level. The groups more represented were Chlorophyta and Bacillariophyta, although Cyanobacteria were also present in significant numbers. The species richness seemed higher in the medium section (two sites) of the studied area (Monção-Valença), although this may be a spurious effect of more samples being analysed for these two sites than for the others. Nevertheless, the upstream site Melgago, presented a significant number of diatom species when compared to that of chlorophytes. This might be due to the fact that in Melgaço the river has more lotic characteristics. Vertical turbulence favours diatoms over other

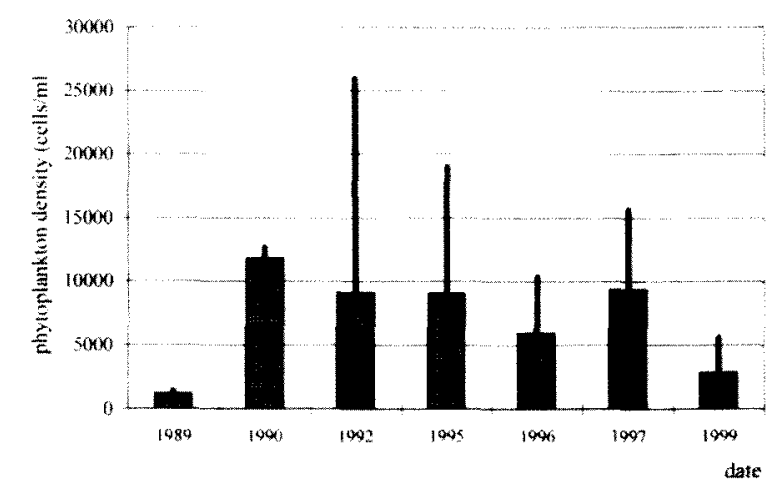

Figure 2. Average annual phytoplankton density (cells $/ \mathrm{ml}$ ) in the international section of Minho River (bar-standard deviation). Densidad anual promedio de fitoplancton (células $/ m l$ ) en el tramo internacional del río Miño (la barra indica la desviación estándur). 
Table 1. Species richness at four sampling points of the international section of Minho river. Riqueza de especies en cuatro estaciones de muestreo del tramo internacional del Miño.

\begin{tabular}{|c|c|c|c|c|}
\hline Species & Seixas/Lanhelas & Valença & Monção & Melgaqo \\
\hline \multicolumn{5}{|l|}{ CYANOBACTERIA } \\
\hline Anabaena pas-aquae & & $\mathrm{X}$ & $X$ & $X$ \\
\hline A. spiroides & & $X$ & & \\
\hline Aphanizomenon flos-aquae & & $\mathrm{X}$ & & \\
\hline Dactylococcopsis irregularis & & $\mathrm{X}$ & $\mathrm{X}$ & \\
\hline Merisrnopedia elegans & & & $X$ & \\
\hline Microcystis aeruginosa & $\mathrm{X}$ & $\mathrm{X}$ & $\mathrm{X}$ & \\
\hline Oscillatoria limosa & & & & $\mathrm{X}$ \\
\hline Pseudanubaena mucicola & & $\mathrm{X}$ & & \\
\hline \multicolumn{5}{|l|}{ CHLOROPHYTA } \\
\hline \multicolumn{5}{|l|}{ Actinastrum fluviatile } \\
\hline A. hantzschii & & $\mathrm{X}$ & $\mathrm{X}$ & \\
\hline Ankistrodesrnus acicularis & & $X$ & & $X$ \\
\hline A. angustus & & $\mathrm{X}$ & $\mathrm{X}$ & $X$ \\
\hline Chlorolobion braunii & & & $X$ & \\
\hline Closterium acicularis & & $\mathrm{X}$ & & \\
\hline Closteriopsis acicularis & & $X$ & & \\
\hline Coelastrum astroideurn & $X$ & $\mathrm{X}$ & $\mathrm{X}$ & \\
\hline C. rnicroporum & & $\mathrm{X}$ & $X$ & \\
\hline C. reticulatum & & $X$ & & \\
\hline Crucigenia quadrata & $\mathrm{X}$ & $\mathrm{X}$ & $\mathrm{X}$ & \\
\hline C. rectangularis & & & $X$ & \\
\hline C. tetrapedia & & $X$ & $\mathrm{X}$ & \\
\hline Crucigeniella apiculatu & & $\mathrm{X}$ & & \\
\hline Dictyosphaerium pulchellum & $\mathrm{X}$ & $\mathrm{X}$ & $\mathrm{X}$ & \\
\hline Hyaloraphidium contortum & & $X$ & $\mathrm{X}$ & $X$ \\
\hline Micractinium pusillurn & & $X$ & $\mathrm{X}$ & $\mathrm{X}$ \\
\hline Oocystis lacustris & $\mathrm{X}$ & & & \\
\hline O. naegeli & & $\mathrm{X}$ & $X$ & \\
\hline Pandorina morum & & $\mathrm{X}$ & $X$ & \\
\hline Pediastruin duplex & & $\mathrm{X}$ & $\mathrm{X}$ & \\
\hline P.tetras & $\mathrm{X}$ & $X$ & $\mathrm{X}$ & \\
\hline Scenedesrnus acutus & & $\mathrm{X}$ & $X$ & $\mathrm{X}$ \\
\hline S. acuminatus & & & $\mathrm{X}$ & \\
\hline S. bicaudatus & & $X$ & $\mathrm{X}$ & $X$ \\
\hline Scenedesrnus ecornis & $X$ & $X$ & $X$ & $\mathrm{X}$ \\
\hline S. magnus & & & $\mathrm{X}$ & \\
\hline S. opoliensis & & $X$ & & \\
\hline S. quadricauda & $\mathrm{X}$ & $X$ & $X$ & $\mathrm{X}$ \\
\hline S. smithii & & & $X$ & \\
\hline Schroederia setigera & $X$ & & & \\
\hline Sphaerocystis schroeteri & & $X$ & & $X$ \\
\hline Staurastrum paradoxum & & $\mathrm{X}$ & $\mathrm{X}$ & \\
\hline S. messikornmeri & $\mathrm{X}$ & $X$ & & \\
\hline Stichococcus bacillaris & $\mathrm{X}$ & & & \\
\hline Tetraedrom caudaturn & & & & $\mathbf{X}$ \\
\hline T. minimum & & $\mathrm{X}$ & $\mathrm{X}$ & $\mathbf{X}$ \\
\hline Treubaria planctonica & & $\mathrm{X}$ & & \\
\hline
\end{tabular}


Table 1. (Cont.)

\section{DIATOMS}

Acknantkes affinis Asterionella formosa Aulacoseira ambigua

A. granulata

Ceratoneis arcus

Cocconeis placentula

Cyclotella glomerata

Diatoma elongatum

D. vulgare

Eunotia pectinalis

Fragilaria acus

Fragilaria capucina

F. crotonensis

F. ulna

Gomphonema constrictum

Melosira varians

Meridion circulare

Navicula cryptocephala

Nitzschia acicularis

$N$. actinastroides

N. palea

Stauroneis anceps

Stepkanodiscus sp.

Surirella robusta

F. ulna

Tabellariafenestrata

T. flocculosa

\begin{tabular}{|c|c|c|}
\hline & $X$ & $X$ \\
\hline$X$ & $X$ & $X$ \\
\hline \multirow[t]{4}{*}{$X$} & X & X \\
\hline & $X$ & $X$ \\
\hline & $X$ & X \\
\hline & $X$ & X \\
\hline \multirow[t]{3}{*}{$X$} & $X$ & $X$ \\
\hline & $X$ & $X$ \\
\hline & X & $X$ \\
\hline \multirow{2}{*}{$X$} & $X$ & $X$ \\
\hline & & $\mathbf{X}$ \\
\hline$X$ & $X$ & $X$ \\
\hline \multirow[t]{4}{*}{$X$} & X & $X$ \\
\hline & & $X$ \\
\hline & & $X$ \\
\hline & $\mathrm{X}$ & \\
\hline \multirow[t]{2}{*}{$X$} & $X$ & $X$ \\
\hline & $X$ & $X$ \\
\hline \multirow[t]{5}{*}{$X$} & $X$ & $X$ \\
\hline & $X$ & $X$ \\
\hline & & $X$ \\
\hline & $X$ & $X$ \\
\hline & & $\mathrm{X}$ \\
\hline \multirow[t]{2}{*}{$\mathrm{X}$} & $X$ & $X$ \\
\hline & $X$ & $X$ \\
\hline
\end{tabular}

\section{CRYSOPHYTA}

Synura uvella

X

\section{CRYPTOPHYTA}

Cryptomonas erosa

C. ovata

Rhodomonas minuta

Total number of species

species by avoidance of sedimentary losses (Sommer, 1991).

Data on Minho River phytoplankton species are scarce (Cerqueira, 1991, Cerqueira \& Cunha, 1992, Vasconcelos, 1995a). Nevertheless, most of the registered species are common to other river systems of North Portugal, such as Lima, Ave or Douro (Vasconcelos, 1995a).

Considering the average density of phytoplankton in the study period and combining all the sites, an important difference is found in 1992 compared to the other sampled years (Fig. 2). In this year we registered the highest phytoplankton density in this section of Minho River during the study period, attaining 63708 cells/ml. In 1991, although only one sample was analysed, a maximum total phytoplankton density of 29020 cells/ml was registered, mostly due to the cyanobacterium Microcystis aeruginosa (27480 cells/ml) (see Fig. 4). 
In fact, 1991 was an exceptionally dry year and cyanobacteria blooms wereregistered in many reservoirs and lakes in Portugal (Vasconcelos, 1994, 1995a). In Barrinha de Mira lake, 163200 cells $/ \mathrm{ml}$ of $M$. aeruginosa were found in May 1991 while in Mira lake the same species attained 60920 cells/ml in September 1991 (Vasconcelos, 1995a). These two lakes are also located in Northern Portugal. Sabater \& Nolla (1991) showed that for the reservoirs of the NW of Spain, namely those of the Minho area, average cell numbers were as follows: Fragilaria crotonenis - 11271 cells/ml, Anabaena variabilis 3236 cells $/ \mathrm{ml}$, Dictyosphaerium pulchelum 3158 cells $/ \mathrm{ml}$. These values match those we obtained during the study period.

In 1992 a survey of the phytoplankton diversity and density in the section Valença/TuyCaminha/Tamuge was done, corresponding to the area affected by tides. During this work, no cyanobacteria blooms were recorded. Maximum cyanobacteria density values were attained in September (Fig. 3). It is interesting to point out that cyanobacteria started to increase in July in the most upstream site in 1992, and in September, Valença/Tuy still presented high densities of cyanobacteria. The highest during this month was found in Lanhelas, close to the mouth

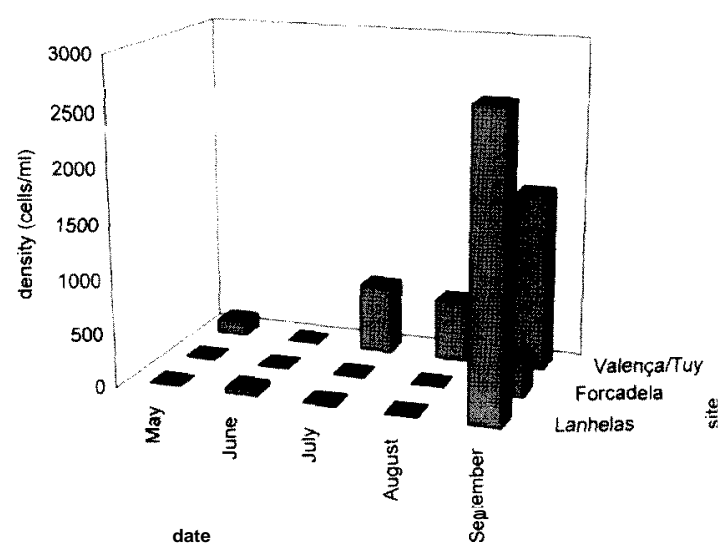

Figure 3. Total cyanobacteria density (cells $/ \mathrm{ml}$ ) in the international section of Minho River (1992). Densidad total de cianobacterias (células/ml) en el tramo internacional del río Miño (1992). of the river, with 2400 cells $/ \mathrm{ml}$ of Microcystis aeruginosa.

No data are available on the cyanobacteria density further upstream, namely in Spanish reservoirs. Nevertheless, we suggest that this increase of cyanobacteria densities in downstream sites may be due to the discharge of cyanobacteria blooms developed in the calmer waters of spanish reservoirs upstream.

Microcystis is common in plankton of mesotrophic to hypertrophic lakes, rivers and ponds and may dominate as nuisance blooms in slow-flowing or stratified waters (Paerl, 1991). It is known that $M$. aeruginosa needs water with high retention times and low salinity to develop (Paerl et al., 1984). It is unlikely that this species develops close to the mouth of the river, where considerable salinity values are easily reached.

Vasconcelos (1995a) reported cyanobacteria blooms in the mouth of Minho River in late August of 1990 and 1991, composed mainly of $M$. aeruginosa. In these two years, the blooms were found to be not toxic by the mouse bioassay (Vasconcelos, 1995a). In the following year, a toxic bloom mainly composed of $M$. aeruginosa was detected in September in Monção. At this time the bloom was hepatotoxic with an intraperitoneal $\mathrm{LD}$, of $35 \mathrm{mg} / \mathrm{kg}$ (Vasconcelos, 1995a). This bloom had microcystin-LR as well as other three non-identified microcystins (Vasconcelos et al., 1996). The toxicity of Cyanobacteria blooms may vary along time and depth axes and changes may be quite fast (Chorus \& Bartram, 1999). Environmental factors such as temperature, nutrients and salinity may also be responsible for shifts in toxicity. These factors may be important in this section of River Minho, as toxicity is higher in upstream sites (i. e. Monção) and decreases or disappears in most downstream sites, close to the mouth of the river. Downstream, salinity may affect toxin production. To clearly test this hypothesis, samples would have to be taken along a longitudinal transect during a bloom period.

There is no pattern in phytoplankton density changes along the salinity gradient (Fig 4). In fact, we did observe the highest density in Valença (63708 cells/ml in 1992), although high 


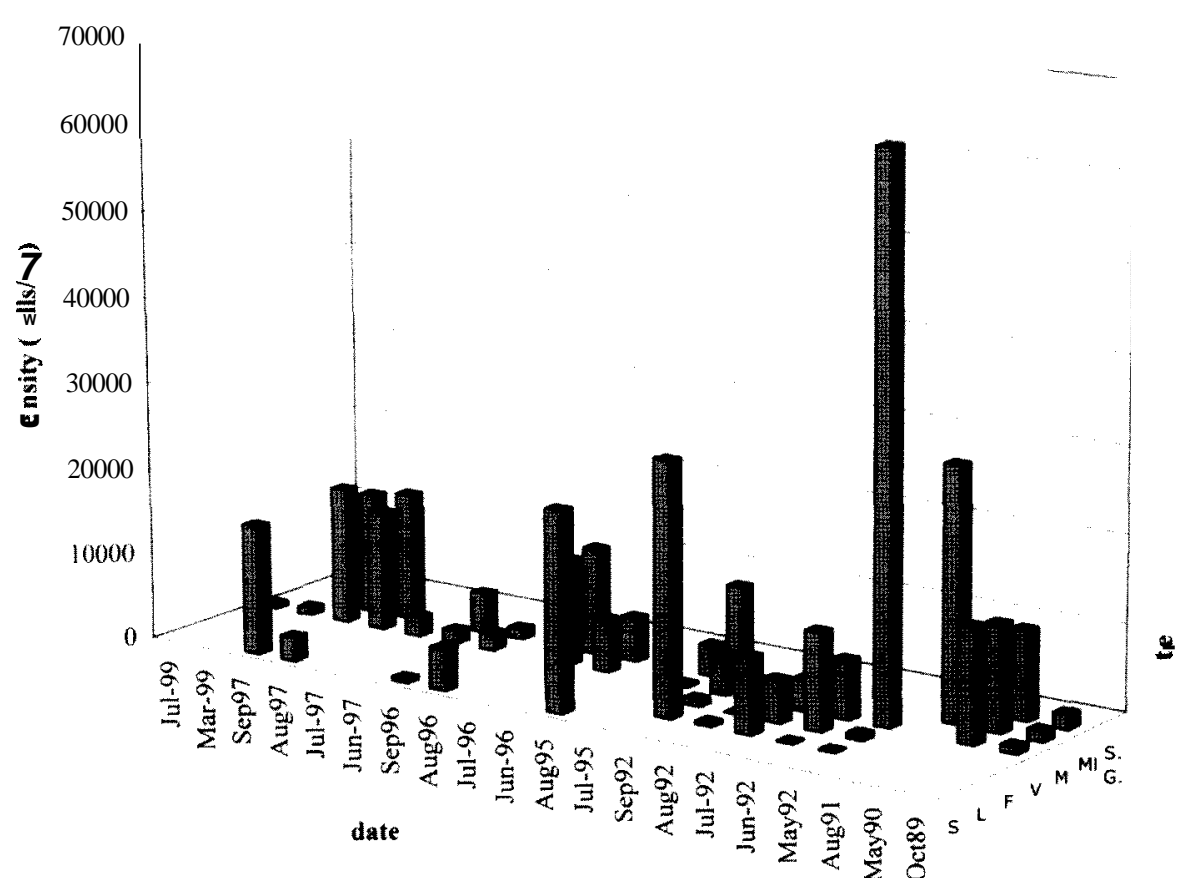

Figure 4. Total phytoplankton density (cells/ml) in the international section of Minho River (1989-1999)( S.G.- S. Gregório, Ml- Melgaço, M-Monção, V-Valença, F-Forcadela, L-Lanhelas, S-Seixas). Densidad totul del fitoplancton (células/ml) en el tramo internacional del río Miño (1989-99) (SC.- Sun Gregorio, MI-Melgaço, M-Monçao, V-Valença, F-Forcadela, L-Lanhelas, S-Seixas).

densities were also found in Seixas, at the river mouth. A more regular sampling strategy needs to be applied so as to test this idea.

The dynamics of the phytoplankton in the lower part of River Minho seems to be dependent largely on two factors. The development of typical planktonic communities in reservoirs upstream the international area and their discharge downstream is one factor. Also, tidal currents may concentrate typical freshwater species in the lower part of the estuary mainly in summer.

From average phytoplankton density values (Fig. 2), River Minho may be considered as eutrophic, according to Margalef (1983). However, if we consider the Trophic State Index (TSI; Carlson, 1977) the TSI values for chlorophyll $a$ obtained at the INAG (Portuguese Water Institute) site classify River Minho as mesotrophic. In fact the TSI chlorophyll a val- ues vary in average between 3.5.6 in Valenqa $(n=34), 39.7$ in Monção $(n=32)$ and 46.1 in Melgaço $(n=19)$. These values were calculated from data obtained between 199.5 and 1998 (Vasconcelos et al., 2000).

Cyanobacteria blooms may accumulate at the estuary of River Minho be filtered by molluses and if they are toxic, transfer toxins along food chains. Mussels accumulate microcystins very rapidly and do not depurate them easily (Vasconcelos, 1995b; Amorim \& Vasconcelos, 1999). Thus, the occurrence of blooms of toxic cyanobacteria may create human health risks.

The phytoplankton community of the River Minho presented regular blooms of cyanobacteria, namely of Microcystis aeruginosa, especially during late August. During the rest of the year the community is composed mainly of Chlorophytes and Diatoms. Total phytoplankton densities fluc- 
tuated around 10000 cells $/ \mathrm{ml}$ on average. Although higher values registrered in 1991. The occurrence of cyanobacteria blooms, toxic in 1995 , points out the need for the regular monitoring of these organisms, especially because water is used for several purposes.

Systematic studies are needed so as to better predict the community dynamics of phytoplankton in this river.

\section{ACKNOWLEDGEMENTS}

The authors are indebt with Dr. Rosário Norton from DRA-Norte for the water samples of 19921998 and to Eng ${ }^{\circ}$ Pedro Baptista and Rui Coelho from AGRI-PRO Ambiente, for financing the 1999 samples. We alsowish to acknowledge two anonymous reviewers who contributed to the revision of this work.

\section{REFERENCES}

AMORIM, A. \& V.M. VASCONCELOS. 1999. Dynamics of microcystins in the mussel Mytilus gulloprovinciulis. Toxicon, 37: 1041-1052.

CARLSON, R.E. 1977. Atrophic state index for lakes. Limnol and Oceunog., 22: 361-370.

CERQUEIRA, M.M. 1991. Caracterização das comunidades algais dos rios Minho, Âncora, Neiva e Tâmega. In: "Avaliação da qualidade du água através de parcimetros biológicos em rios do norte de Portugal". IZAN-FCUP, Porto: 43-70.

CERQUEIRA, M.M. \& M.J. CUNHA, 1992. Avaliação da qualidade bioldgica da agua em meios lóticos através da caracterização das comunidades algais. Actas da 3" Conferência Nacional du Qualidade do Ambiente. Vol I: 198-200.

CHORUS, I. \& J. BARTRAM,. 1999. Toxic cyanobacteria in Water: Ed. E \& FN SPON, 4 I6 pp.

LUND, J.W.G., C. KIPLING, \& E.D. LE CREN, 1958. The inverted microscope methods of estimating algal numbers and the statistical basis of esti- mation by counting. Hydrobiologia, 1I :143-170.

MARGALEF, R. 1983. Limnologia. Ed. Omega, Barcelona.

MARTINEZ-ANSEMIL, E. \& P. MEMBIELA,. 1992. The low mineralised and fast turnover water courses of Galicia. Limneticu, 8: 125-130.

PAERL, H. W., 1991. Growth and reproductive strategies of freshwater blue-green algae (cyanobacteria). In: Growth and reproductive strutegies of freshwater phytoplankton. Sandgreen, C.D. (ed.): 261-315. Cambridge University Press.

PAERL, H.W., P.T. BLAND, H.H. BLACKWELL, \& N.D. BOWLES,. 1984. The effects of salinity on the potential of blue-green algal (Microcystis aeruginosa) bloom. Univ. N.C. Sea Grant Program Working Paper (4-1).

SABATER, S. \& J. NOLLA 1991. Distributional patterns of phytoplankton in Spanish reservoirs: first results and comparison after fifteen years. Verh. Internat. Verein. Limnol., 24: 1371-1375.

SOMMER, U. I991. Growth and survival strategies of planktonic diatoms. In: Growth and reproductive strutegies of freshwater phytoplankton. Sandgreen, C.D. (ed.): 227-260. Cambridge University Press.

VASCONCELOS, V. 1994. Toxic cyanobacteria (blue-green algae) in Portuguese freshwaters. Arch. Hydrobiol., 130: 439-45I.

VASCONCELOS, V.M. 1995a. Toxicologin de cianobactérias. Distribuição de cianobactérias tóxicas e suas toxinas em aguas doces portuguesus. Bioacumulação em hivalves. $\mathrm{PhD}$ Thesis. Faculdade de Ciências do Porto.

VASCONCELOS, V.M. 1995b. Uptake and depuration of the peptide toxin microcystin-LR in the mussel Mytilus galloprovinciallis. Aquatic Toxicology, 32: 227-237.

VASCONCELOS, V.M., M.M. CERQUEIRA \& M. COELHO,. 2000. Plano de Bacia do Rio Minho. Diagndstico, Inventário e análise da situação no rio Minhn. Fitoplâncton e zooplâncton. FCUP, Porto: 46 pp.

VASCONCELOS, V.M., K. SIVONEN, W.R. EVANS, W.W. CARMICHAEL \& M. NAMIKOSHI, 1996. Hepatotoxic microcystin diversity in cyanobacterial blooms collected in Portuguese freshwaters. Water Reseurch, 30: 2377-2384. 